Proc. Estonian Acad. Sci. Geol., 1997, 46, 1, 3-16

\title{
CLINOPYROXENES FROM A PLUTONIC FORMATION OF THE ICELANDIC CENTRAL VOLCANO
}

\author{
Alvar SOESOO \\ Geoloogia Instituut (Institute of Geology), Estonia pst. 7, EE-0001 Tallinn, Eesti (Estonia) \\ Tartu Ulikooli geoloogia instituut (Institute of Geology, University of Tartu), Vanemuise 46, \\ EE-2400 Tartu, Eesti (Estonia) \\ Presented by V. Puura
}

Received 2 January 1996, accepted 24 January 1997

Abstract. Over 300 microprobe analyses of clinopyroxenes (CPXs) from ultramafic rocks $\left(\mathrm{En}_{42-45} \mathrm{Fs}_{12-17} \mathrm{Wo}_{38-43}\right)$, olivine- $\left(\mathrm{En}_{42-44} \mathrm{Fs}_{15-16} \mathrm{Wo}_{40-43}\right)$ and quartz-tholeiitic $\left(\mathrm{En}_{40-43} \mathrm{Fs}_{15-17} \mathrm{Wo}_{41}\right)$ gabbros, and hybrid rocks $\left(\mathrm{En}_{40-33} \mathrm{Fs}_{19-28} \mathrm{Wo}_{41-39}\right)$ in the Thverartindur central volcanic complex, SE Iceland, were studied. The augites and Ti-augites (Ca-poor pyroxene was not found in the Thverartindur complex) are usually homogeneous or very slightly zoned exhibiting compositional overlap by En-Fs-Wo values. Thverartindur CPXs are similar to those of Skaergaard intrusion and Kap Edvard Holm formation in eastern Greenland by major elements, but differ in the content of minor elements and do not display a distinctive Fe-enrichment trend. However, Thverartindur CPXs are close to the compositions of CPX crystallizing in early stages from a tholeiitic basaltic liquid, $\mathrm{En}_{43} \mathrm{Fs}_{17} \mathrm{Wo}_{40}$, while a fractionated endmember-CPX of $\mathrm{En}_{29} \mathrm{Fs}_{32} \mathrm{Wo}_{39}$ is determined in one hybrid sample only. Thverartindur CPXs were crystallized under low pressure $(P<2 \mathrm{kbar})$ conditions in the temperature interval of $1100-1150^{\circ} \mathrm{C}$. These conditions can be realized above a depth of $5 \mathrm{~km}$, which is consistent with the general geology of central volcanic complexes in Iceland. Great variability of the Wo component in homogeneous CPX crystals besides random minor element distribution necessitates the involvement of late- and postmagmatic factors controlling the CPX compositional spectrum. The modelled crystallization history shows that in plagioclase An numbers are systematically higher as compared to natural ones, corresponding well with large variability of CPX Wo number. This fact leads to an assumption that Ca exchange reaction occurred at a late stage of crystallization and diffusional effects can be considered as an important modifying factor. Rather than primary magma composition, in situ crystallization, Soret separation, and the late-stage effects are considered as processes responsible for CPX compositional variation.

Key words: clinopyroxene crystallization, modelling, plutonic rock, central volcano, Iceland. 


\section{INTRODUCTION}

Since clinopyroxenes (CPXs) contain nearly all elements occurring in basaltic rocks, they are like small-scale magmatic systems revealing characteristics applicable over larger basaltic magmatic systems. For this reason CPXs are important for understanding magmatic evolution.

Slowly cooled and strongly fractionated bodies of tholeiitic magmas are characterized by two compositionally and structurally different pyroxene trends which coexist through a large spectrum of fractionated series. Such coexistence of pyroxenes, each of which may display exsolution features, is a diagnostic character of tholeiitic intrusions, contrasting with the single pyroxene lacking exsolution of alkali basic intrusions. The pyroxenes showing exsolutions are absent in quickly cooled volcanic rocks (Cox et al., 1989). Usually, at early stages the calcium-poor pyroxene trend is represented by primary orthopyroxene, this giving way to monoclinic pigeonite which, however, almost always inverts to orthorhombic pyroxene on slow cooling. The exsolution story of these pyroxenes is that a calcium-rich parent exsolves a calcium-poor daughter, and vice versa. Pyroxenes in small tholeiitic intrusions may show exsolution textures, although the broad, regular lamellae variety is less common.

The low-Ca pyroxene that crystallizes from normal oceanic basalt (MORB) at low pressure is pigeonite (e.g. Shibata, 1976; Sigurdsson, 1981; Perfit \& Fornaris, 1983; Elthon, 1987). The pseudoliquidus phase diagram of Grove \& Bryan (1983) further shows that pigeonite is the low-Ca pyroxene that crystallizes from MORBs at $1 \mathrm{~atm}$., whereas orthopyroxene would not crystallize from MORB-type liquids at this pressure. However, experimental studies of MORB liquids indicate that with increasing pressure orthopyroxene replaces pigeonite as the low-Ca pyroxene.

This study aims to describe chemistry of pyroxenes from the ultramafic rocks, olivine- and quartz-tholeiitic gabbros and hybrid rocks in the Thverartindur central volcanic complex, SE Iceland. Detailed geology and petrology of this complex are presented in Annels (1967), Newman (1967), Bromann \& Soesoo (1994), and Soesoo (1995a, 1995b, 1995c). An application of the principal component analysis on CPX chemical composition is discussed by Soesoo (1996).

\section{MATERIAL AND METHODS}

The material studied was collected and analysed by the author during the twoyear research period in Iceland. Over 300 CPX microprobe analyses were made on the Thverartindur plutonics ranging from ultramafic to hybrid rock types. The analyses were performed on an ARL-SEMQ instrument at Nordic 
Volcanological Institute, Reykjavik, Iceland. The analytical conditions were: beam potential $15 \mathrm{kV}$, current $80 \mathrm{nA}$, and the counting times $10 \mathrm{~s}$ for the peak and $4 \mathrm{~s}$ for the background. Crystallization pressure and temperature $(P T)$ have been evaluated applying the empirical methods by Soesoo (1995a, 1996). Using the results from thermodynamic modelling by the COMAGMAT software (Ariskin et al., 1993), the natural and calculated CPX compositions were juxtaposed.

\section{PETROGRAPHY AND ELEMENT RELATIONSHIP IN THE THVERARTINDUR CLINOPYROXENES}

The Thverartindur gabbros and hybrid rocks are mainly medium- to very coarse-grained indicating a slow cooling rate for the formation. No CPX exsolutions of lamellae or even blebs have been found. A few orthopyroxenes observed in the ultramafic rocks occur often as cores inside the CPX crystals. This contradiction between the assumed slow cooling rate and the presence of one homogeneous CPX, augite, and Ti-augite, strongly favours low pressure and forced cooling without conspicuous convective thermal buffering.

Thverartindur CPXs are treated according to the rock types defined from whole-rock chemistry (Soesoo, 1995b). Representative data of chemical analyses of the Thverartindur CPXs are presented in the table; statistics of the distribution of En, Fs, and Wo components is demonstrated in Fig. 1. The geometry of these distributions gives a general idea about the petrogenetic interrelationship of distinctive rock types.

The augites from the ultramafic dyke, sill, and xenolith are usually uniform or slightly zoned exhibiting the average composition of $\mathrm{En}_{42-45} \mathrm{Fs}_{12-17} \mathrm{Wo}_{38-43}$ (Table). Cores of augite yield crystal/rock (crystal/liquid) $\mathrm{Fe}-\mathrm{Mg}$ exchange coefficients, Kd, from 0.73 (sample FE063), through 0.84 (FE065) to 1.76 (HV028) indicating pyroxene crystallization under the disequilibrium conditions. It is noted that the pyroxenes from the xenolith have a slightly more homogeneous chemical composition.

Within the olivine-tholeiitic gabbros, the CPXs reveal predominantly uniform compositions: $\mathrm{En}_{42-44} \mathrm{Fs}_{15-16} \mathrm{Wo}_{40-43}$ (Table), while in a few cases reverse zoning has been observed. The calculated augite/rock Kds vary from 0.41 to 0.53 . Sample FE081 displays a wide spectrum of CPX core compositions clearly distinguishing two generations defined by En, Fs, and Wo numbers in addition to different zoning patterns expressed by En and Wo numbers. The different CPX generations are also defined by the $\mathrm{Fe}-\mathrm{Mg}$ distribution coefficients: the first generation has $\mathrm{Kds}$ ranging from $0.8-1.6$, which is comparable with the CPXs in ultramafic rocks. The second generation displays $\mathrm{Kds}$ of $0.36-0.58$. 
Selected clinopyroxene analyses from the Thverartindur rock types. R, rim; C, core. FE and HV indicate Fellsa and Hvannadalur intrusions, respectively. Cations on the basis of six oxygens

\begin{tabular}{l|c|c|c|c|c|c|c|c|c|c|c|c}
\hline \multirow{3}{*}{$\begin{array}{l}\text { Ele- } \\
\text { ments }\end{array}$} & \multicolumn{4}{|c|}{ Ultramafics } & \multicolumn{7}{c}{ Olivine-tholeiites } \\
\cline { 2 - 12 } & FE063 & FE063 & FE065 & FE044 & FE044 & FE045 & FE045 & FE045 & FE081 & FE081 & FE081 & FE081 \\
\cline { 2 - 12 } & C & C & R & C & C & R & C & R & C & C & C \\
\hline
\end{tabular}

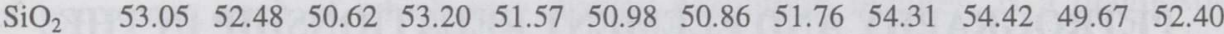

$\begin{array}{lllllllllllll}\mathrm{TiO}_{2} & 0.91 & 1.12 & 1.09 & 0.70 & 1.02 & 1.11 & 1.08 & 1.02 & 0.33 & 1.11 & 0.36 & 1.09\end{array}$

$\begin{array}{lllllllllllll}\mathrm{Al}_{2} \mathrm{O}_{3} & 1.77 & 1.81 & 1.68 & 1.48 & 2.52 & 2.19 & 1.74 & 1.66 & 2.78 & 2.10 & 6.96 & 1.72\end{array}$

$\begin{array}{lllllllllllll}\mathrm{Cr}_{2} \mathrm{O}_{3} & 0.19 & 0.24 & 0.34 & 0 & 0.01 & 0.01 & 0 & 0.01 & 0.06 & 0.05 & 0.42 & 0.20\end{array}$

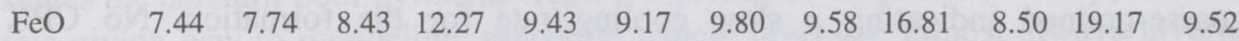

$\begin{array}{lllllllllllll}\mathrm{MnO} & 0.24 & 0.17 & 0.17 & 0.37 & 0.21 & 0.20 & 0.28 & 0.22 & 0.34 & 0.17 & 0.17 & 0.27\end{array}$

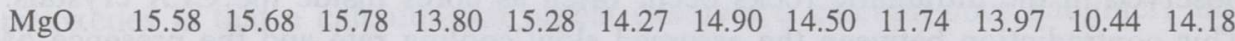

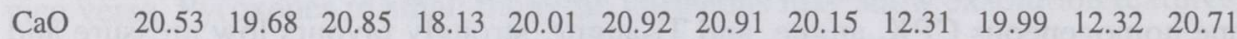

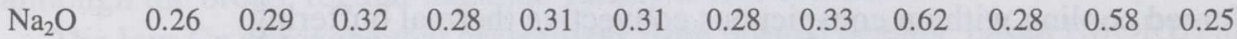

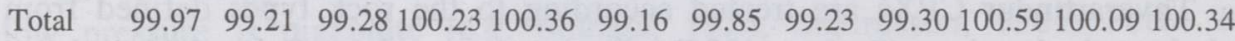

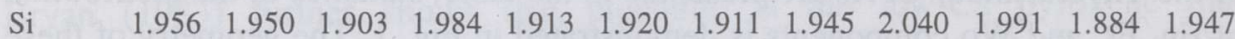

$\begin{array}{lllllllllllll}\mathrm{Ti} & 0.025 & 0.031 & 0.031 & 0.020 & 0.028 & 0.031 & 0.030 & 0.029 & 0.009 & 0.031 & 0.010 & 0.030\end{array}$

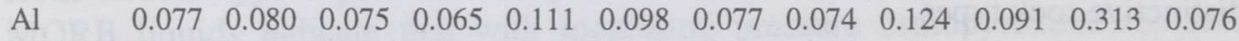

$\begin{array}{lllllllllllll}\text { Cr } & 0.006 & 0.007 & 0.010 & 0.000 & 0.000 & 0.000 & 0.000 & 0.000 & 0.002 & 0.001 & 0.013 & 0.006\end{array}$

$\begin{array}{lllllllllllll}\mathrm{Fe}^{2+} & 0.229 & 0.240 & 0.265 & 0.382 & 0.292 & 0.288 & 0.307 & 0.300 & 0.527 & 0.260 & 0.607 & 0.295\end{array}$

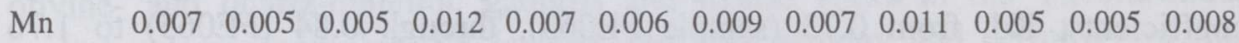

$\begin{array}{llllllllllllll}\mathrm{Mg} & 0.856 & 0.868 & 0.884 & 0.767 & 0.845 & 0.801 & 0.834 & 0.811 & 0.657 & 0.761 & 0.590 & 0.785\end{array}$

$\begin{array}{llllllllllllll}\mathrm{Ca} & & 0.811 & 0.783 & 0.839 & 0.724 & 0.795 & 0.844 & 0.841 & 0.811 & 0.495 & 0.783 & 0.500 & 0.824\end{array}$

$\begin{array}{lllllllllllll}\mathrm{Na} & 0.019 & 0.021 & 0.023 & 0.020 & 0.022 & 0.023 & 0.020 & 0.024 & 0.045 & 0.020 & 0.043 & 0.018\end{array}$

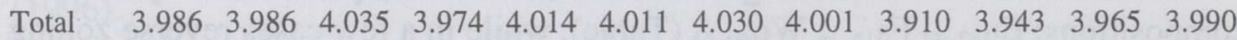

$\begin{array}{lllllllllllll}\text { En } & 45 & 46 & 44 & 41 & 44 & 41 & 42 & 42 & 39 & 42 & 35 & 41 \\ \text { Fs } & 12 & 13 & 13 & 20 & 15 & 15 & 16 & 16 & 31 & 14 & 36 & 16 \\ \text { Wo } & 43 & 41 & 42 & 39 & 41 & 44 & 42 & 42 & 29 & 43 & 29 & 43\end{array}$




\begin{tabular}{|c|c|c|c|c|c|c|c|c|c|c|}
\hline \multirow{3}{*}{ Elements } & \multicolumn{4}{|c|}{ Quartz-tholeiites } & \multicolumn{6}{|c|}{ Hybrid rocks } \\
\hline & FE079 & FE079 & \begin{tabular}{|l|} 
HV012 \\
\end{tabular} & HV012 & FE046 & FE046 & FE048 & FE048 & FE048 & FE048 \\
\hline & $\mathrm{C}$ & $\mathrm{R}$ & $\mathrm{R}$ & $\mathrm{C}$ & $\mathrm{R}$ & $\mathrm{C}$ & $\mathrm{C}$ & $\mathrm{C}$ & $\mathrm{C}$ & $\mathrm{C}$ \\
\hline $\mathrm{SiO}_{2}$ & 51.52 & 51.39 & 50.85 & 1.58 & 50.73 & & & 49.64 & 50.64 & 52.16 \\
\hline $\mathrm{TiO}_{2}$ & 0.82 & 1.05 & 1.02 & 1.08 & 0.80 & 1.02 & 0.64 & 0.57 & 0.49 & 0.63 \\
\hline $\mathrm{Al}_{2} \mathrm{O}_{3}$ & 1.02 & 1.13 & 1.31 & 1.15 & 1.74 & 1.60 & 0.63 & 0.61 & 0.57 & 0.88 \\
\hline $\mathrm{Cr}_{2} \mathrm{O}_{3}$ & 0.05 & 0 & 0.01 & 0.04 & 0 & 0 & 0 & 0 & 0 & 0 \\
\hline $\mathrm{FeO}$ & 9.86 & 10.31 & 9.39 & 9.39 & 11.89 & 12.70 & 15.78 & 16.45 & 17.35 & 14.34 \\
\hline $\mathrm{MnO}$ & 0.20 & 0.24 & 0.23 & 0.24 & 0.27 & 0.36 & 0.47 & 0.49 & 0.56 & 0.42 \\
\hline $\mathrm{MgO}$ & 15.69 & 15.12 & 15.86 & 16.19 & 13.91 & 13.72 & 12.06 & 11.50 & 10.59 & 12.81 \\
\hline $\mathrm{CaO}$ & 19.78 & 20.38 & 20.66 & 20.45 & 19.69 & 18.10 & 18.70 & 18.92 & 19.57 & 18.66 \\
\hline $\mathrm{Na}_{2} \mathrm{O}$ & 0.32 & 0.29 & 0.32 & 0.29 & 0.21 & 0.28 & 0.23 & 0.23 & 0.26 & 0.25 \\
\hline Total & 99.26 & 99.91 & 99.65 & 100.41 & 99.24 & 98.85 & 99.97 & 98.41 & 100.03 & 100.15 \\
\hline $\mathrm{Si}$ & 1.939 & 1.929 & 1.911 & 1.920 & 1.927 & 1.945 & 1.969 & 1.947 & 1.961 & 1.975 \\
\hline $\mathrm{Ti}$ & 0.023 & 0.030 & 0.029 & 0.030 & 0.023 & 0.029 & 0.018 & 0.017 & 0.014 & 0.018 \\
\hline $\mathrm{Al}$ & 0.045 & 0.050 & 0.058 & 0.051 & 0.078 & 0.072 & 0.029 & 0.028 & 0.026 & 0.039 \\
\hline $\mathrm{Cr}$ & 0.001 & 0.000 & 0.000 & 0.001 & 0.000 & 0.000 & 0.000 & 0.000 & 0.000 & 0.000 \\
\hline $\mathrm{Fe}^{2+}$ & 0.310 & 0.323 & 0.295 & 0.292 & 0.377 & 0.404 & 0.504 & 0.539 & 0.561 & 0.453 \\
\hline $\mathrm{Mn}$ & 0.006 & 0.008 & 0.007 & 0.008 & 0.009 & 0.012 & 0.015 & 0.016 & 0.018 & 0.013 \\
\hline $\mathrm{Mg}$ & 0.880 & 0.846 & 0.888 & 0.898 & 0.787 & 0.778 & 0.687 & 0.672 & 0.611 & 0.722 \\
\hline $\mathrm{Ca}$ & 0.797 & 0.819 & 0.831 & 0.815 & 0.801 & 0.738 & 0.766 & 0.795 & 0.811 & 0.757 \\
\hline $\mathrm{Na}$ & 0.023 & 0.021 & 0.023 & 0.021 & 0.015 & 0.021 & 0.017 & 0.017 & 0.020 & 0.018 \\
\hline Total & 4.024 & 4.026 & 4.042 & 4.036 & 4.017 & 3.999 & 4.005 & 4.031 & 4.022 & 3.995 \\
\hline En & 44 & 43 & 44 & 45 & 40 & 41 & 35 & 34 & 31 & 37 \\
\hline Fs & 16 & 16 & 15 & 15 & 19 & 21 & 26 & 27 & 28 & 23 \\
\hline Wo & 40 & 41 & 41 & 41 & 41 & 38 & 39 & 40 & 41 & 39 \\
\hline
\end{tabular}



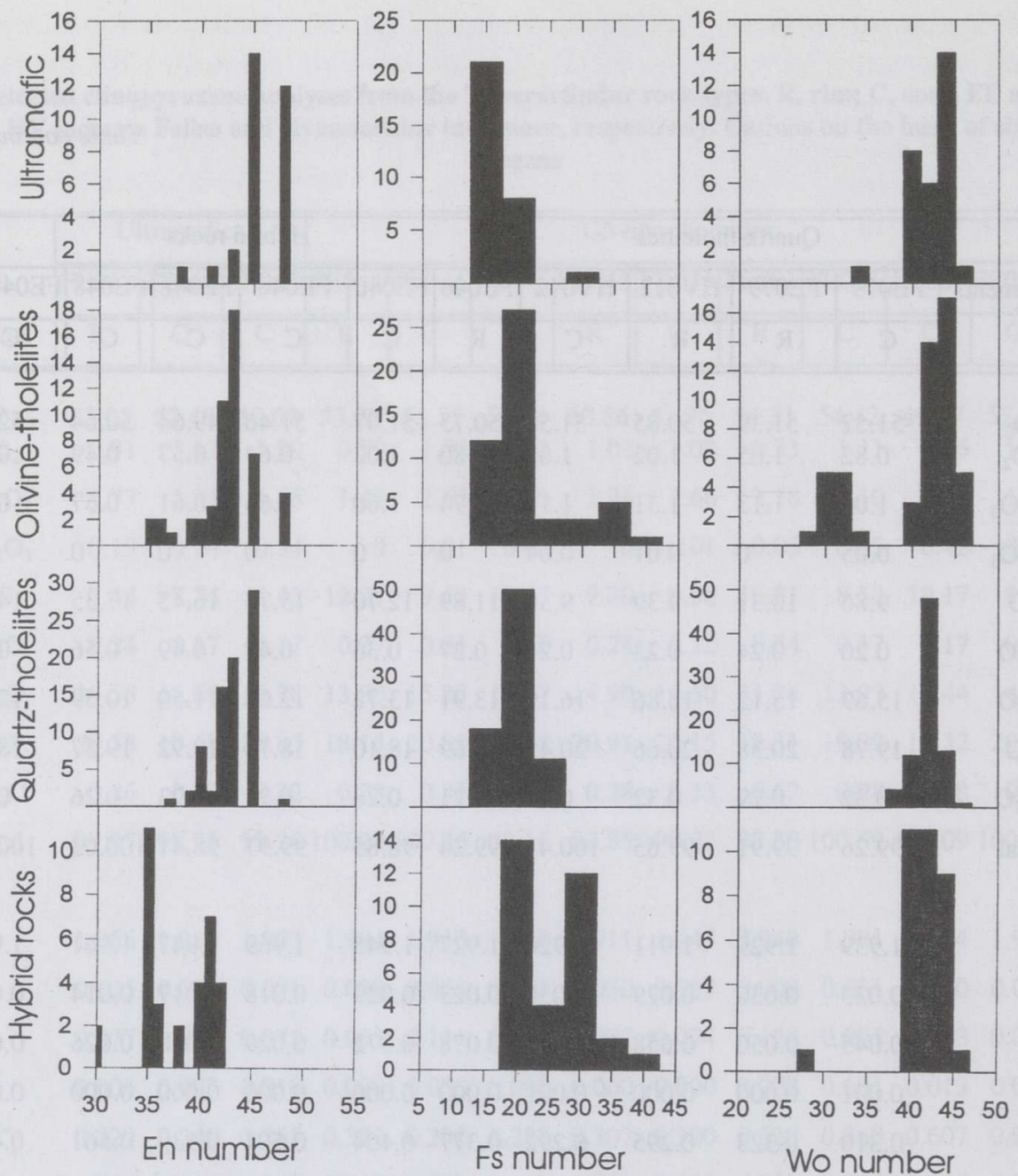

Fig. 1. Distribution of En, Fs, and Wo of Thverartindur clinopyroxenes. The ranking of En-Fs-Wo components is chosen according to the specifics of these values in order to minimize "random" values. The most stable En component has counter-step 1, Wo has step 2, and Fs has step 5. Vertical axis shows the number of analyses.

CPXs from the quartz-tholeiitic gabbros are uniform, but sometimes exhibit very slight normal zoning. This slight zoning is expressed either by Fs (sample FE079) or by En and Wo (sample HV012). The average CPX composition is $\mathrm{En}_{40-43} \mathrm{Fs}_{15-17} \quad \mathrm{Wo}_{41}$ (Table). The cores of augites yield crystal/rock Fe-Mg exchange coefficients from 0.21 to 0.30 , which are comparable with those determined experimentally for MORBs by Grove \& Bryan (1983) and Tormey et al. (1987) at $1 \mathrm{~atm}$. 
Two samples (FE046, FE048) of hybrid rocks were analysed (Table). The augites are small uniform or zoned crystals. Normal and reverse zoning are expressed either by Fs and Wo (sample FE046) or by En and Fs (sample FE048). Samples FE046 and FE048 have clearly different Mg and Fe contents, while sample FE046 exhibits the common Thverartindur CPX of $\mathrm{En}_{40} \mathrm{Fs}_{19} \quad \mathrm{Wo}_{41}$. Sample FE048 displays more Fe-rich and Mg-poor CPXs of $\mathrm{En}_{33} \mathrm{Fs}_{28} \mathrm{Wo}_{39}$. $\mathrm{Fe}-\mathrm{Mg}$ exchange coefficients are very uniform, ranging from 0.27 to 0.3 , which is consistent with crystallization from MORB at $1 \mathrm{~atm}$.

The major element distribution in the Thverartindur CPXs can be followed in Figs. 1 and 2. The minor element distribution is summarized below. The $\mathrm{TiO}_{2}$ content varies from 0.5 to $1.3 \mathrm{wt} \%$, while that of $\mathrm{Al}_{2} \mathrm{O}_{3}$ ranges from 0.5 to $4 \mathrm{wt} \%$, usually lying within 1-3 wt\%. A few CPXs of sample FE081 display unusually high $\mathrm{Al}_{2} \mathrm{O}_{3}$ contents up to $7 \mathrm{wt} \%$. The $\mathrm{MnO}$ content is commonly $0.2-$ $0.3 \mathrm{wt} \%$, while the CPXs from the ultramafic and hybrid rock types display slightly higher values $-0.35-0.5 \mathrm{wt} \% \mathrm{MnO}$. The $\mathrm{Cr}_{2} \mathrm{O}_{3}$ content is low, varying from 0.01 to $0.08 \mathrm{wt} \%$. A common feature of CPXs from all rock types is a systematically negative $\mathrm{TiO}_{2}-\mathrm{MnO}$ covariation. The $\mathrm{Al}_{2} \mathrm{O}_{3}$ and $\mathrm{TiO}_{2}$ contents increase usually with an increase of $\mathrm{Mg \#}$ number. There are two trends corresponding to olivine- and quartz-tholeiitic gabbros, while the CPXs from olivine-tholeiites have a slightly higher $\mathrm{Al}_{2} \mathrm{O}_{3}$ and form a steeper slope in $\mathrm{Al}_{2} \mathrm{O}_{3}$ vs $\mathrm{Mg} \#$ than those of quartz-tholeiitic gabbros (not shown in Figs. 1, 2).

Slight systematic differences of minor element contents between CPX cores and rims were detected only in the $\mathrm{TiO}_{2}$ content. Some olivine- and quartztholeiitic gabbros (samples FE047, FE045) exhibit a directed change of $\mathrm{TiO}_{2}$, $\mathrm{Al}_{2} \mathrm{O}_{3}, \mathrm{Cr}_{2} \mathrm{O}_{3}$, and $\mathrm{Na}_{2} \mathrm{O}$, where concentrations of certain elements vary from rim through core to the other side of a crystal by up to $10 \mathrm{wt} \%$. This directed change is observed also by En, Fs, and Wo components and can possibly be related to diffusion of certain elements.

The correlative relationship between whole-rock and CPX compositions was studied. It is important to mention that $\mathrm{CaO}$ and $\mathrm{Na}_{2} \mathrm{O}$ in $\mathrm{CPXs}$ exhibit the weakest correlations with all other elements. Significant positive correlation ( 0.69 to 0.78 ) is observed between $\mathrm{MnO}$ in CPX and incompatible elements such as $\mathrm{P}_{2} \mathrm{O}_{5}, \mathrm{Ba}, \mathrm{Y}$, and $\mathrm{Zr}$ in the host rock. This may indicate the role of manganese as an evolutionary index of CPX crystallization from tholeiitic basaltic magma. A slightly weaker but negative correlation of $\mathrm{Mg \#}$ number of $\mathrm{CPX}$ and $\mathrm{K}_{2} \mathrm{O}$, $\mathrm{P}_{2} \mathrm{O}_{5}, \mathrm{Ba}, \mathrm{Y}$, and $\mathrm{Zr}$ in rock supports this assumption. The $\mathrm{P}_{2} \mathrm{O}_{5}$ content in the host rock displays the strongest correlation indicating an important controlling role of phosphorus in CPX crystallization. An increase in $\mathrm{P}_{2} \mathrm{O}_{5}$ in more evolved basaltic magmas increases a modal $\mathrm{Pl} / \mathrm{Px}$ ratio as reported by Toplis et al. (1994). It seems therefore plausible that phosphorus has strong influence on CPX. The major and trace elements of CPX cores analysed exhibit much weaker correlations than those from each rock type separately. This would be expected 
assuming distinctive initial magma compositions, slightly differing temperature regime and processes of crystallization.

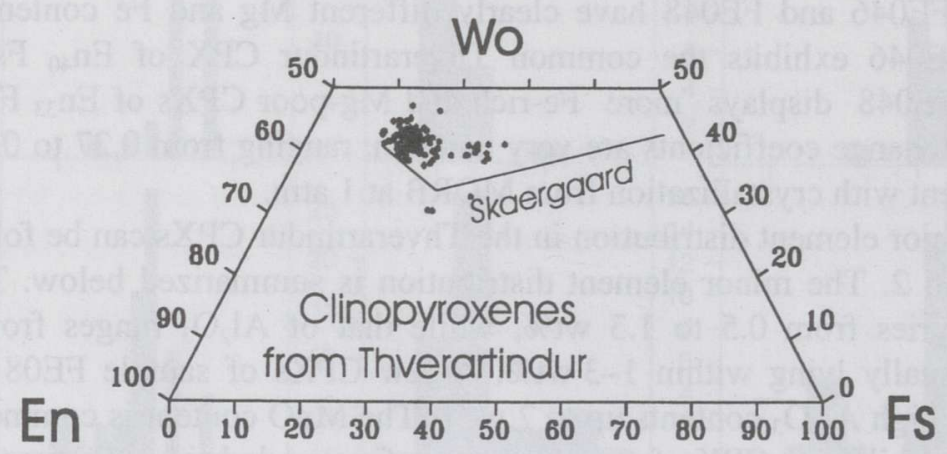

Fig. 2. Pyroxene quadrilateral plot of Thverartindur clinopyroxenes (dots). Evolutionary trend of Skaergaard clinopyroxenes is presented for reference.

\section{DISCUSSION AND CONCLUSIONS}

\section{PT conditions of the Thverartindur CPX crystallization}

There are several studies on the application of CPX compositions as geothermometers and geobarometers. Quite commonly two pyroxene pairs are used for geothermometry (e.g. Lindsley \& Dixon, 1983; Wells, 1977; Nickel et al., 1985). $\mathrm{Fe}-\mathrm{Mg}$ exchange reactions between mineral pairs were used in geothermometry for garnet-lherzolite assemblages (Finnerty \& Boyd, 1984; Carswell \& Gibb, 1987). Geobarometers involve multimineral assemblages (Mukhopadhyay et al., 1992) or mineral components as the enstatite, diopside, and aluminous phase (Wood, 1974). Because the Thverartindur plutonics are predominantly plagioclase-clinopyroxene rocks, the estimations of $P T$ based on well-known geothermobarometers are aggravated.

Here an attempt is made to evaluate these parameters employing an empirical $P T$-space which is based only on a single CPX composition (Soesoo, 1995a). Thverartindur CPXs occupy the low pressure $(P<2$ kbar $)$ field within the temperature interval of $1100-1150{ }^{\circ} \mathrm{C}$ (not shown here; see Soesoo, 1995a). These conditions can be realized above a depth of $5 \mathrm{~km}$ which is consistent with the general geology of central volcanic complexes in Iceland. Some CPXs from the olivine-tholeiitic unit fall inside the $2 \mathrm{kbar}$ field. This can be explained by two ways: first, by uncertainties arising from the empirical nature of the $P T$-space; and second, some of the CPXs may be relicts crystallizing in a much deeper magma body. The CPXs from an ultramafic xenolith tend to plot on or 
close to the 2 kbar pressure field corresponding well with crystallization at a greater depth.

For comparison, the Thverartindur CPXs are plotted on the pyroxene quadrilateral together with the Skaergaard trend (Fig. 2). Summarizing the CPX compositional characteristics, it can be noted that Thverartindur CPXs are similar to those of Skaergaard intrusion and Kap Edvard Holm formation in eastern Greenland by En-Wo-Fs values, but differ in the content of minor elements (see Wager \& Brown, 1968; Bernstein et al.,1992). Also, they show a distinctive Fe-enrichment trend. However, Thverartindur CPXs are close to the compositions of CPX crystallizing in early stages from a tholeiitic basaltic liquid, $\mathrm{En}_{43} \mathrm{Fs}_{17} \mathrm{Wo}_{40}$, but a fractionated endmember-CPX of $\mathrm{En}_{29} \mathrm{Fs}_{32} \mathrm{Wo}_{39}$ has been determined in one hybrid sample only. More evolved quartz-gabbros display a CPX composition of $\mathrm{En}_{41} \mathrm{Fs}_{16} \mathrm{Wo}_{41}$, not much differing from a more primitive variety. Similar to the Kap Edvard Holm layered gabbro complex in Greenland and Austurhorn composite intrusion in SE Iceland, Ca-poor pyroxene was not found in the Thverartindur complex. It is difficult to relate the lack of the Ca-poor phase to an increase in silica activity in the melt, which can in principle terminate the crystallization of $\mathrm{Ca}$-poor pyroxene balanced by the reappearance of Fe-rich olivine. This process is documented in the late stages of fractionation in Bushveld and Skaergaard intrusions. In the Thverartindur rocks, the olivine phase occurs rarely and is mostly accompanied with the ultramafic rocks. There is no evidence of extensive olivine breakdown reactions either. However, these reactions do not explain the presence of the unzoned and unexsolved single CPX in the Thverartindur complex. This situation resembles the crystallization process in alkali basalts. On the other hand, neither dyke nor plutonic rocks convincing alkali affinity of parental magmas have been found. Therefore, there is no reason to suggest an alkaline original magma.

\section{Modelled versus natural CPX compositions}

As assumed, the Thverartindur gabbros represent near-magmatic liquid compositions of only local modification (Soesoo, 1995b). Therefore it is possible to model the crystallization history. The compositional changes of CPXs through a wide crystallization temperature range have been modelled using the COMAGMAT program compiled by Ariskin et al. (1993). Thermodynamic calculations on two samples, FE045 and HV012, correspondingly representing the olivine- and quartz-tholeiitic magmatic compositions, show probable crystallization temperatures of $1140^{\circ} \mathrm{C}$ and $1110-1120^{\circ} \mathrm{C}$, respectively (Fig. 3), which are in good agreement with data from an empirical $P T$-plot. It is important to mention that the CPX compositional trend with respect to temperature is oxygen fugacity dependent. As Fig. 3 shows, temperature, oxygen fugacity, and initial magma composition do not satisfy compositional options in natural samples. The inference following from this is that an additional process 
controlling CPX chemistry has obscured initial pyroxene composition. Modelled plagioclase An numbers (Fig. 3) are systematically higher for more primitive olivine-tholeiitic samples corresponding well with a large variability of the CPX Wo number (Ca-component). This fact leads to an assumption that the Ca exchange reaction did occur at a late stage of crystallization and even postmagmatic diffusional effects can be considered as an important modifying factor of the CPX composition. However, unzoned CPX grains may support the idea about the late homogenization phenomenon, which has affected primarily slightly zoned crystals. Repeated heating followed by slow cooling, characteristic of the oceanic spreading centre environment, offers special conditions favourable for homogenization of CPX and gradual plagioclase modification through the $\mathrm{Ca}-\mathrm{Na}$ exchange.

\section{Plausible processes responsible for CPX compositional variation}

The results obtained from thermodynamic modelling show that the closest fit with natural compositions may be achieved by equilibrium crystallization in QFM+1 oxygen buffer (Soesoo, 1995b). As Fig. 3 shows, in natural samples the variation of En, Fs, Wo, and An numbers is much greater compared with the calculated ones. However, the calculated equilibrium phases are more calcic and magnesian. The observed compositions may be attained supposing that the residium liquid is not isolated from the crystallization front. This process, referred to as in situ crystallization, has been described amongst many plutonics (Langmuir, 1989). Relying upon trace element distribution in host rock, some escape of residual liquid (probably few per cent) is likely to have occurred. This, on the other hand, can produce less magnesian pyroxenes with a higher Ca-component which is in disequilibrium with other components. CPX compositional variation seems to depend also on the solidification zone and interface geometry.

As one plausible disequilibrium process, enabling slight modification of the crystal-liquid relationship, the Soret effect has been considered (Walker \& DeLong, 1982, 1984; Lesher, 1986). The Soret effect arises from the internal redistribution of elements within a substance in response to an imposed temperature gradient and is called thermal diffusion. In thin sill-like bodies like Thverartindur gabbros, thermal diffusion may be highly important along the margins of the gabbro body. Unfortunately, the sampling performed is not satisfactory for quantifying this process with respect to the others involved. A proof for the presence of Soret separation may be a sample with mineral generations exhibiting direct shift of major elements through a single mineral grain (described above). 


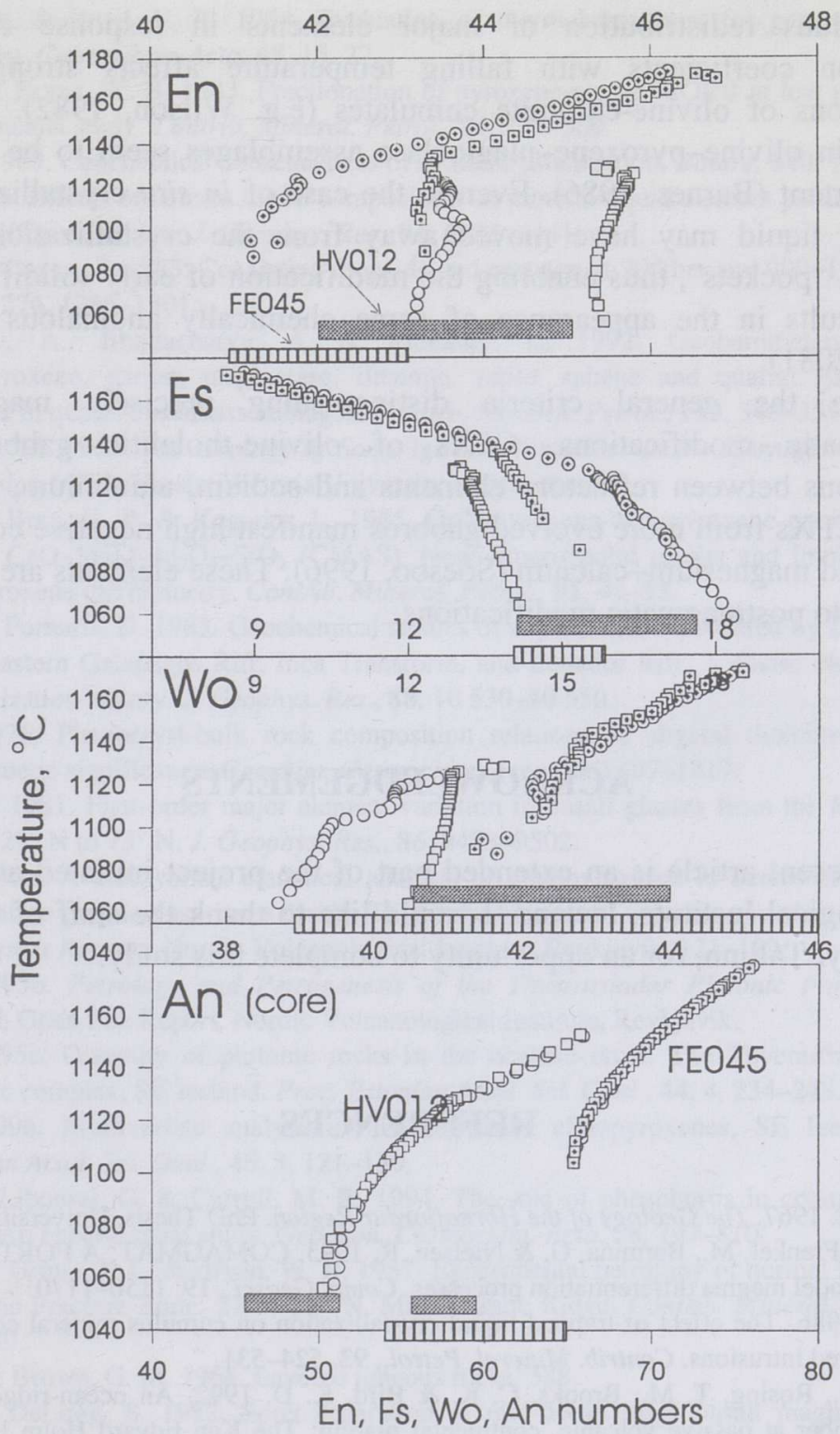

Fig. 3. Modelled clinopyroxene (En, Fs, and Wo components) and plagioclase (An component) compositions of primitive (FE045) and evolved (HV012) gabbros. Striped and dotted boxes indicate the range of observed compositions in primitive and evolved gabbro samples, respectively. Different parameters of equilibrium crystallization are used: circles - sample HV012 crystallized in NNO oxygen buffer; circles with crosses - FE045, NNO buffer; rectangles - HV012, QFM buffer; rectangles with crosses - FE045, QFM buffer. 
Subsolidus redistribution of major elements in response to changing distribution coefficients with falling temperature affects strongly mineral compositions of olivine-chromite cumulates (e.g. Wilson, 1982). The effects recorded in olivine-pyroxene-plagioclase assemblages seem to be smaller but still important (Barnes, 1986). Even in the case of in situ crystallization, some remaining liquid may have moved away from the crystallization front and trapped in "pockets", thus enabling the modification of early solidified crystals, which results in the appearance of some chemically anomalous CPXs (see sample FE081).

Despite the general criteria distinguishing precisely magmatic and postmagmatic modifications, CPXs of olivine-tholeiitic gabbros exhibit substitutions between refractory elements and sodium, aluminium, and silicon, whereas CPXs from more evolved gabbros manifest high negative covariance of sodium and magnesium+calcium (Soesoo, 1996). These elements are likely to be subjected to postmagmatic modifications.

\section{ACKNOWLEDGEMENTS}

The present article is an extended part of the project initiated at the Nordic Volcanological Institute, Iceland. I would like to thank the staff of the Institute of Geology, Tallinn, for an opportunity to complete this study.

\section{REFERENCES}

Annels, A. E. 1967. The Geology of the Hornafjordur Region. PhD Thesis, University of London.

Ariskin, A., Frenkel, M., Barmina, G. \& Nielsen, R. 1993. COMAGMAT: A FORTRAN program to model magma differentiation processes. Comp. Geosci., 19, 1150-1170.

Barnes, S. 1986. The effect of trapped liquid crystallization on cumulus mineral compositions in layered intrusions. Contrib. Mineral. Petrol., 93, 524-531.

Bernstein, S., Rosing, T. M., Brooks, C. K. \& Bird, K. D. 1992. An ocean-ridge type magma chamber at passive volcanic, continental margin: The Kap Edvard Holm layered gabbro complex, East Greenland. Geol. Mag., 129, 437-456.

Bromann, M. \& Soesoo, A. 1994. Structure and petrology of a central volcanic complex in SE. Iceland. (Abstract). Journal of Icelandic Geological Society, 29-30.

Carswell, D. A. \& Gibb, F. G. F. 1987. Evaluation of mineral thermometers and barometers applicable to garnet lherzolite assemblages. Contrib. Mineral. Petrol., 95, 499-511.

Cox, K. G., Bell, J. D. \& Pankhurst, R. J. 1989. The Interpretation of Igneous Rocks. London, UNWIN HYMAN, Boston.

Elthon, D. 1987. Petrology of gabbroic rocks from Mid-Cayman Rise Center. J Geophys. Res., 92, 658-682. 
Finnerty, A. A. \& Boyd, F. R. 1984. Evaluation of thermobarometers for garnet-peridotites. Geochim. Cosmochim. Acta, 48, 15-27.

Grove, T. L. \& Bryan, W. B. 1983. Fractionation of pyroxene-phyric MORB at low pressure: An experimental study. Contrib. Mineral. Petrol., 84, 293-309.

Langmuir, C. 1989. Geochemical consequences of in situ crystallization. Nature, 340, 199-205.

Lesher, C. 1986. Effects of silicate liquid composition on mineral-liquid element partitioning from Soret diffusion studies. J. Geophys. Res., 91, 6123-6141.

Lindsley, D. \& Dixon, S. 1983. Coexisting diopside and enstatite at $20 \mathrm{kbar}$ and $900-1200{ }^{\circ} \mathrm{C} . \mathrm{Am}$. J. Sci., 276, 1285-1301.

Mukhopadhyay, A., Bhattacharya, A. \& Mohanty, L. 1992. Geobarometers involving clinopyroxene, garnet, plagioclase, ilmenite, rutile, sphene and quartz: Estimation of pressure in quartz-absent assemblages. Contrib. Mineral. Petrol., 110, 346-354.

Newman, T. C. M. 1967. The Geology of Some Igneous Intrusions in the Hornafjordur Region, S.E. Iceland. $\mathrm{PhD}$ Thesis, Victoria University of Manchester.

Nickel, K. G., Brey, G. P. \& Kogarko, L. 1985. Orthopyroxene-clinopyroxene equilibria in the system $\mathrm{CaO}-\mathrm{MgO}-\mathrm{Al}_{2} \mathrm{O}_{3}-\mathrm{SiO}_{2}$ (CMAS): New experimental results and implications for two-pyroxene thermometry. Contrib. Mineral. Petrol., 91, 44-53.

Perfit, M. J. \& Fornaris, D. 1983. Geochemical studies of abyssal lavas recovered by DSRV Alvin from Eastern Galapagos Rift, Inca Transform, and Ecuador Rift, 2. Phase chemistry and crystallization history. J. Geophys. Res., 88, 10 530-10 550.

Shibata, T. 1976. Phenocryst-bulk rock composition relations of abyssal tholeiites and their petrogenetic significance. Geochim. Cosmochim. Acta, 40, 1407-1417.

Sigurdsson, H. 1981. First-order major element variation in basalt glasses from the Mid-Atlantic Ridge: $29^{\circ} \mathrm{N}$ to $73^{\circ}$ N. J. Geophys. Res., 86, 9483-9502.

Soesoo, A. 1995a. A multivariate statistical analysis of clinopyroxenes to derive crystallization temperature-pressure estimates for the Thverartindur central volcanic complex, SE Iceland. In Progress Reports. Nordic Volcanological Institute, Reykjavik, 121-122.

Soesoo, A. 1995b. Petrology and Petrogenesis of the Thverartindur Plutonic Formation, SE Iceland. Open File Report. Nordic Volcanological Institute, Reykjavik.

Soesoo, A. 1995c. Diversity of plutonic rocks in the oceanic crust: The Thverartindur central volcanic complex, SE Iceland. Proc. Estonian Acad. Sci. Geol., 44, 4, 234-248.

Soesoo, A. 1996. Multivariate analysis of Thverartindur clinopyroxenes, SE Iceland. Proc. Estonian Acad. Sci. Geol., 45, 3, 121-130.

Toplis, M. J., Libourel, G. \& Carroll, M. R. 1994. The role of phosphorus in crystallization of basalt: An experimental study. Geochim. Cosmochim. Acta, 58, 797-810.

Tormey, D. R., Grove, T. L. \& Bryan, W. B. 1987. Experimental petrology of normal MORB near the Kane Fracture Zone: $22^{\circ}-25^{\circ}$ N, Mid-Atlantic Ridge. Contrib. Mineral. Petrol., 96, 121-139.

Wager, L. R. \& Brown, G. M. 1968. Layered igneous rocks. 588.

Walker, D. \& DeLong, S. 1982. Soret separation of mid-ocean ridge basalt magma. Contrib. Mineral. Petrol., 79, 231-240.

Walker, D. \& DeLong, S. 1984. A small Soret effect in spreading center gabbros. Contrib. Mineral. Petrol., 85, 203-208.

Wells, P. R. A. 1977. Pyroxene thermometry in simple and complex systems. Contrib. Mineral. Petrol., 62, 129-139.

Wilson, A. 1982. The geology of the Great "Dyke", Zimbabwe: The ultramafic rocks. J. Petrol., 23, 240-292.

Wood, B. J. 1974. The solubility of alumina in orthopyroxene coexisting with garnet. Contrib. Mineral. Petrol., 46, 1-15. 


\section{KLINOPÜROKSEENID ISLANDI TSENTRAALSE VULKAANI PLUTOONILISTEST KIVIMITEST}

\section{Alvar SOESOO}

On uuritud Thverartinduri vulkaani (Island) plutoonilistest kivimitest pärit augiitide ja Ti-augiitide keemilist koostist. Elektronsondanalüüsi, empiirilisi statistilisi meetodeid ja arvutimodelleerimist kasutades on tuvastatud, et nimetatud klinopürokseenid on kristalliseerunud madalarõhulises $(<2$ kbar $)$ keskkonnas ja temperatuurivahemikus $1100-1150{ }^{\circ} \mathrm{C}$. Modelleeritud ja mõõdetud koostise vahe, aga samuti elementide jaotuse spetsiifika lubavad oletada, et klinopürokseenid Thverartinduri plutoonilises formatsioonis on allunud hilis- ja pärastmagmalistele muutustele ning ei kajasta primaarmagmalist tasakaalulist koostist.

\section{КЛИНОПИРОКСЕНЫ ИЗ ПЛУТОНИЧЕСКИХ ПОРОД ИСЛАНДСКОГО ЦЕНТРАЛЬНОГО ВУЛКАНА}

\section{Алвар СОЕСОО}

Изучен химический состав авгитов и титановых авгитов из плутонических пород Исландского центрального вулкана. Анализом электронного зондирования, эмпирическими статистическими методами и моделированием выявлено, что изученные клинопироксены кристаллизовались в среде низкого давления (<2 кбар) при температурах $1100-1150{ }^{\circ} \mathrm{C}$. Разница между смоделированным и проанализированным составом пироксенов, а также специфика распространения элементов позволяют предположить, что тверартиндурские клинопироксены - это продукты поздне- и послемагматических изменений, они не отражают первичного магматического равновесного состава. 